\title{
Pengaruh Model Problem Based Learning (PBL) Melalui Lesson Study Terhadap Kemampuan Berpikir Kritis Siswa
}

\author{
${ }^{1}$ Norma Yunita, ${ }^{2}$ Laxmi Zahara, ${ }^{3}$ Khaerus Sahidi \\ ${ }^{1}$ Prodi Pendidikan Fisika, FMIPA, Universitas Hamzanwadi, Jln. TGKH. M. Zainuddin \\ Abdul Madjid No. 132 Pancor Selong, Lombok Timur, NTB, 83611 \\ Email Korespondensi: ${ }^{1}$ ynorma76@gmail.com; ${ }^{2}$ laxmi_zahara@yahoo.com; \\ khaerussyahidi@hamzanwadi.ac.id
}

\begin{tabular}{|c|c|}
\hline Arti & bstract \\
\hline & \multirow[b]{2}{*}{$\begin{array}{l}\text { The Effect Of Problem Based Learning (PBL) Model Through Lesson Study } \\
\text { On Students' Critical Ability. This study aimed at detemining the effect of } \\
\text { Problem Based Learning Model on the ability of students' critical thinking } \\
\text { through lesson on the topic of effort and energy. The method of research was } \\
\text { an experimental research by using post-test-one control group design. } \\
\text { Experimental class was treated by problem based learning, while the control } \\
\text { class was taught by conventional learning through lesson study. Population of } \\
\text { this research was the high school at Al Hamzar, Tembeng Putik of the X grade } \\
\text { which consisted of two classes. Those were X Mathematics and natural science } \\
1 \text { and X Mathematics and Natural Science } 2 \text { with the total number or students } \\
\text { was 58. The sampling thechnique applied was saturated sampling technique. } \\
\text { Then, the instrument used in the present research was essay test which } \\
\text { contained } 6 \text { items. The test arrangement followed the indicators of critical } \\
\text { thinking with a variety of possible answers. Having implemented both in the } \\
\text { experimental and in the control class, there were improvements in learning } \\
\text { process in tems of managing the time, the students and doing aperception. } \\
\text { Testing hyphoteshis result by uisng t-test showed t-test = } 1 \text {. } 25 \text { and t-table in } \\
\text { signifance level was } 5 \% \text { was } 0 \text {. O7, so t-test> t-table which meant the } \\
\text { alternative hyphothesis (Ha) was accepted and null hyphothesis (Ho) was } \\
\text { rejected, it could be concluded that problem based learning thorugh lesson } \\
\text { study was significantly effective in students'critical ability on the topic of effort } \\
\text { and energy for the tenth garade students at Al Hamzar high school. }\end{array}$} \\
\hline $\begin{array}{l}\text { Keyword } \\
\text { Problem } \\
\text { Lesson St } \\
\text { Thinking }\end{array}$ & \\
\hline Infor & Abstrak \\
\hline & \multirow[b]{2}{*}{$\begin{array}{l}\text { Penelitian ini bertujuan untuk mengetahui pengaruh Model Problem Based } \\
\text { Learning terhadap kemampuan Berpikir Kritis Siswa Melalui Lesson pada } \\
\text { pokok bahasan Usaha dan Energi. Jenis penelitian ini adalah penelitian } \\
\text { eksperimen dengan desain Posttest-Only Control Group. Kelas eksperimen } \\
\text { diberi perlakuan dengan Model pembelaran Problem Based Learing melalui } \\
\text { Lesson Study. Sedangkan kelas kontrol menggunakan pembelajaran } \\
\text { konvensional melalui Lesson Study. Populasi dalam penelitian ini adalah siswa } \\
\text { SMA Al-Hamzar Tembeng Putik kelas X yang terdiri atas } 2 \text { kelas yaitu kelas X } \\
\text { MIPA } 1 \text { dan X MIPA } 2 \text { dengan jumlah siswa } 58 \text { orang. Teknik pengambilan } \\
\text { sampel dengan teknik sampel jenuh. Instrumen yang digunakan dalam } \\
\text { penelitian ini adalah tes berupa essay yang berjumlah } 6 \text { butir soal. Penyusunan } \\
\text { tes ini mengacu pada indikator berpikir kritis dengan berbagai macam } \\
\text { kemungkinan jawaban. Berdasarkan pelaksanaan Lesson Study pada kelas } \\
\text { eksperimen dan kontrol diperoleh perbaikan pada proses pelaksanaan } \\
\text { pembelajaran, dari segi pengorganisasian waktu dan siswa serta saat melakukan } \\
\text { apersepsi. Hasil uji hipotesis menggunakan uji-t didapatkan t-hitung = 1.25 } \\
\text { dan t-tabel pada taraf signifikan 5\% yaitu 0,07. dengan demikian t-hitung > } \\
\text { t-tabel yang berarti hipotesis yang diajukan diterima atau Ha diterima dan } \\
\text { Ho ditolak, artinya bahwa "Ada pengaruh pembelajaran Problem Based } \\
\text { Learning melalui Lesson Study terhadap kemampuan berpikir kritis siswa pada } \\
\text { materi usaha dan energi kelas X SMA Al-Hamzar Tembeng Putik". }\end{array}$} \\
\hline & \\
\hline
\end{tabular}


Sitasi: Yunita, N., Zahara, L., \& Syahidi, K. Pengaruh Model Problem Based Learning (PBL) Melalui Lesson Study Terhadap Kemampuan Berpikir Kritis Siswa. Kappa Journal, 4(2), 233-239.

\section{PENDAHULUAN}

Kemajuan ilmu pengetahuan yang semakin pesat menuntut perkembangan dalam berbagai bidang khususnya dalam bidang pendidikan. Pada konsep dan implementasi kurikulum 2013, kemampuan berpikir jernih dan kritis menjadi alasan untuk pengembangan kurikulum yang dipaparkan pada kompetensi masa depan. Berpikir kritis menurut Ennis (1995) adalah berpikir secara beralasan dan reflektif denngan menekankan pada pembuatan keputusan tentang apa yang harus dipercaya atau dilakukan. Ennis menyatakan indikator dari keterampilan berpikir kritis siswa ada 5 yaitu: 1). Memberikan jawaban sementara (elementary clarification), 2). Membangun keterampilan dasar (basic support), 3). Membuat inferensi (inferring), 4). Membuat penjelasan lebih lanjut (advanced clarification), dan 5). Mengatur strategi dan taktik (strategies and tactics). Salah satu Model pembelajaran inovatif yang menuntut upaya kritis siswa untuk memperoleh pengetahuan adalah model pembelajaran Problem Based Learning. Lloyd-Jones, Margeston, dan Bligh dalam (Miftahul Huda, 2013: 271) menjelaskan fitur-fitur penting dalam pelaksanaan PBL (Problem-Based Learning), yaitu: menginisiasi pemicu/masalah awal (initiating trigger), meneliti isu-isu yang diidentifikasi sebelumnya, dan memanfaatkan pengetahuan dalam memahami lebih jauh situasi masalah. Dalam pelaksanaan proses pembelajaran agar lebih optimal diperlukan suatu kegiatan yang dapat meningkatkan keprofesionalan dari guru. Menurut Manabu Sato (2012), di Jepang dalam sekolah komunitas belajar, Lesson Study diadakan mulai dari 30 kali sampai 100 kali setahun. Menurut Sato Masaaki (2012), Lesson Study adalah suatu kegiatan serta filosofi. LS meliputi kegiatan untuk menyusun RPP, melakukan open class, melakukan refleksi dan mengarsipkan catatan kegiatan pembelajaran. Tujuan penelitian ini adalah untuk mengetahui pengaruh model PBL (Problem Based Learning) melalui Lesson Study terhadap kemampuan berpikir kritis siswa kelas $\mathrm{X}$ semester genap pada materi Usaha dan Energi SMA Al-Hamzar Tembeng Putik Tahun Ajaran 2016/2017. Berdasarkan kajian teori yang telah dipaparkan maka dapat diambil hipotesis sebagai berikut: Terdapat pengaruh model PBL (Problem Based Learning) melalui Lesson Study terhadap kemampuan berpikir kritis siswa kelas X semester genap pada materi Usaha dan Energi SMA Al-Hamzar Tembeng Putik Tahun Ajaran 2016/2017.

\section{METODE}

Jenis penelitian ini adalah penelitian Eksperimen, menggunakan desain Posttest-Only Control Group. Penelitian ini telah dilaksanakan di SMA Al-Hamzar Tembeng Putik dengan populasi dalam penelitian ini adalah sebanyak 58 orang siswa. Cara menentukan pengambilan sampel dalam penelitian ini adalah menggunakan tehnik sampling jenuh, adalah teknik penentuan sampel bila semua anggota populasi digunakan sebagai sampel (Sugiyono, 2010: 68). Kelas Eksperiment dan kontrol menggunakan pola Lesson Study, perbedaanya kelas eksperimen diajarkan dengan model pembelajaran Problem Based Learning dan kelas control diajarkan dengan metode pembelajaran konvensional. Variabel bebas dalam penelitian ini adalah Model pembelajaran Problem Based Learning (PBL) melalui Lesson Study sedangkan variabel terikat dalam penelitian ini adalah kemampuan berpikir kritis. Dalam penelitian ini, peneliti menerapkan teknik pengumpulan data melalui tes. Tes yang digunakan dalam penelitian ini yaitu tes kemampuan berpikir kritis only postest. Adapun instrumen yang digunakan dalam penelitian ini adalah tes berupa essay yang berjumlah 6 butir soal yang telah 
dihasilkan melalui uji validitas dan reliabilitas. Penyusunan tes ini mengacu pada tes berpikir kritis yang menjajaki berbagai macam kemungkinan jawaban. Pengolahan data dalam penelitian ini menggunakan analisis statistik, yaitu Uji Normalitas dan Uji Homogenitas. Selanjutnya untuk menentukan penerimaan dan penolakan hipotesis, jika data dinyatakan berdistribusi normal, maka untuk menguji hipotesis digunakan uji-t (Sugiyono, 2012: 138).

\section{HASIL DAN PEMBAHASAN}

\section{Lesson Study Siklus 1 Kelas Eksperimen}

Plan siklus 1 dilaksanakan pada hari kamis tanggal 11 Mei 2017. Masukan dari team Lesson Study mengenai RPP yang penulis jabarkan yaitu: 1). Kompetensi dasar yang dimasukkan kedalam RPP hanya point penting dari kompetensi dasar yang akan dilaksanakan pada pembelajaran tersebut, 2). Metode diskusi tidak perlu dimasukkan, 3). Penilaian antar peserta didik tidak perlu; 4). Indikator yang dimasukkan terlalu banyak; dan 5) Sintak model pembelajaran masih bersifat umum. Do dan See/refleksi dilaksanakan pada hari jumat di ruang $\mathrm{X}$ MIPA $^{2}$. Adapun masukan observer diantaranya adalah: 1). Komunikasi siswa dengan guru sudah baik, 2). Posisi duduk siswa kurang teratur; 3) proses pembelajaran sudah cukup baik. 4). Apersepsi kurang menarik atau kurang pas. 5). Guru kurang memperhatikan siswa, ada banyak siswa yang tidak ikut bekerja sama dalam berdiskusi kelompok. 6). Waktu yang tersedia tidak digunakan secara maksimal dan banyak waktu yang terbuang pada pertemuan pertama. 7). Waktu yang digunakan lebih lebih dari waktu jam pelajaran; 8). Respon siswa sebagian besar bagus terhadap penyampaian materi dari guru model.

\section{Lesson Study Siklus 1 Kelas Kontrol}

Plan dilaksanakan pada hari jumat 12 Mei 2017 di ruang X MIPA 2 dengan masukan yaitu: 1) indicator dan tujuan pembelajaran yang dicantumkan terlalu banyak dalam 1 pertemuan. 2). pada kegiatan dan waktu pembelajaran masih bersifat umum lebih dirincikan lagi supaya lebih jelas. Do dan See dilaksanakan pada hari sabtu tanggal 13 Mei 2017 di ruang X MIPA ${ }^{1}$. Adapun masukan observer pada saat open class adalah sebagai berikut: 1). pada awal pembelajaran siswa masih dibiarkan dalam keadaan ribut. 2). Siswa banyak yang sibuk sendiri dan diam. 3). Siswa laki-laki masih dibiarkan ribut dalam kelas.

\section{Lesson Study Siklus 2 Kelas Eksperimen}

Plan dilaksanakan pada hari kamis 18 Mei 2017 di taman kampus dengan masukan observer sebagai berikut: 1) indikator dan tujuan pembelajaran yang dicantumkan sudah diperbaiki. 2). pada kegiatan dan waktu pembelajaran sudah dirincikan pada tahap-tahap yang akan dilaksanakan oleh siswa. 3). Format penilaian sikap dicantumkan. Do dan See dilaksanakan pada tanggal 19 Mei 2017 di kelas X MIPA ${ }^{2}$ dengan masukann observer pada open class sebagai berikut: 1.) siswa dan guru sudah mulai ada hubngan timbal balik. 2). pada proses pembelajaran sudah cukup baik. 3). Apersepsi menarik karena ada perbaikan dari pertemuan yang sebelumnya, 4). siswa sudah mulai aktif dalam kegiatan yang dilakukan oleh guru. 5). pengaturan waktu sudah cukup baik. 6). siswa mulai memberikan respon yang positif kepada guru dan mengalami sedikit peningkatan dari pertemuan sebelumnya.

\section{Lesson Study Siklus 2 Kelas Kontrol}

Plan dilaksanakan pada hari senin tanggal 15 Mei 2017 di taman kampus dengan masukan yang diberikan yaitu: 1). indicator dan tujuan pembelajaran yang dicantumkan sudah sesuai. 2). pada kegiatan dan waktu pembelajaran sudah dirincikan. 3). pada penilaian sudah disesuaikan dengan kegiatan pembelajaran yang ingin dicapai. 4). RPP yang dibuat sudah diperbaiki teknik dan isi yang akan digunakan dalam kegiatan pembelajaran. Do dan See dilaksanakan pada hari selasa tanggal 16 Mei 2017 di kelas X MIPA ${ }^{1}$ dengan masukan 
dari observer pada Open Class sebagai berikut: 1) siswa mulai memperhatikan materi yang diberikan oleh guru model, tidak seperti pertemuan yang sebelumnya pertemuan yang kedua siswa terorganisir dengan baik. 2). siswa memperhatikan penjelasan guru model. Jadi, dari penjelasan yang dijabarkan dari siklus 1 dan 2 pada kelas eksperimen dan kontrol mengalami perbaikan pada proses pelaksanaan pembelajaran, dari segi pengorganisasian waktu dan siswa serta perbaikan saat melakukan apersepsi.

\section{Siklus 1}

Berdasarkan hasil penelitian yang dilakukan di SMA Al-Hamzar Tembeng Putik, maka diperoleh data yang menunjukan aktivitas siswa dalam proses pembelajaran. Selain dari itu terdapat beberapa hasil pembelajaran yang diperoleh setelah penulis melakukan penelitian. Adapun hasil evaluasi kelas atau kelompok eksperimen pada siklus 1 didapatkan skor tertinggi yaitu 70 dan skor terendah yaitu 50 dengan rata-rata 54,3. Sedangkan dari kelas atau kelomSpok kontrol diperoleh skor tertinggi 60 dan skor terendah 25 dengan rata-rata 49. Hasil evaluasi siklus 1 dapat dilihat pada tabel 4.1 berikut :

Tabel 4.1 Data Hasil Evaluasi Kelompok Eksperimen dan Kontrol

\begin{tabular}{lcccc}
\hline Kelas & $\begin{array}{c}\text { Jumlah } \\
\text { Data }\end{array}$ & $\begin{array}{c}\text { Nilai } \\
\text { Tertinggi }\end{array}$ & $\begin{array}{c}\text { Nilai } \\
\text { Terendah }\end{array}$ & $\begin{array}{c}\text { Rata- } \\
\text { rata }\end{array}$ \\
\hline Eksperimen & 28 & 70 & 50 & 54,3 \\
\hline Kontol & 30 & 60 & 25 & 49 \\
\hline
\end{tabular}

\section{Siklus 2}

Berdasarkan penelitian dan pengumpulan data yang diperoleh dari kelompok atau kelas eksperimen didapatkan skor tertinggi yaitu 88 dan skor terendah yaitu 66, dengan rata-rata adalah 77. Sedangkan dari kelompok atau kelas kontrol diperoleh skor tertinggi 75 dan skor terendah adalah 46 dengan rata-rata 60. Data hasil evaluasi untuk kelas eksperimen dan kelas kontrol dapat dilihat pada Tabel 4.2 di bawah.

Tabel 4.2 Data Hasil Evaluasi Kelompok Eksperimen dan Kontrol

\begin{tabular}{lcccc}
\hline Kelas & $\begin{array}{c}\text { Jumlah } \\
\text { Data }\end{array}$ & $\begin{array}{c}\text { Nilai } \\
\text { Tertinggi }\end{array}$ & $\begin{array}{c}\text { Nilai } \\
\text { Terendah }\end{array}$ & $\begin{array}{c}\text { Rata- } \\
\text { rata }\end{array}$ \\
\hline Eksperimen & 28 & 88 & 66 & 77 \\
\hline Kontol & 30 & 75 & 46 & 60 \\
\hline
\end{tabular}

Uji normalitas data dimaksudkan untuk mengetahui normal atau tidaknya keadaan data yang akan diolah, sehingga dapat diketahui bahwa data yang diperoleh tersebut berdistribusi normal atau tidak. Pengujian dilakukan dengan mengunakan chi kuadrat $\left(\chi^{2}\right)$. Data yang diuji diambil dari hasil evaluasi kemampuan berpikir kritis masing-masing kelas seperti yang ada pada lampiran. Hasil uji normalitas ini disajikan pada Tabel 4.5 dibawah dan secara rinci dapat dilihat pada lampiran.

Tabel 4.5 Hasil Uji Normalitas Kelas Eksperimen dan Kontrol

\begin{tabular}{lccc}
\hline \multicolumn{1}{c}{ Kelas } & $\chi_{\text {hitung }}^{2}$ & $\chi_{\text {tabel }}^{2}$ & Kriteria \\
\hline Eksperimen & 10.398 & 11.070 & Terdistribusi Normal \\
\hline Kontrol & 2.034 & 11,070 & Terdistribusi Normal \\
\hline
\end{tabular}




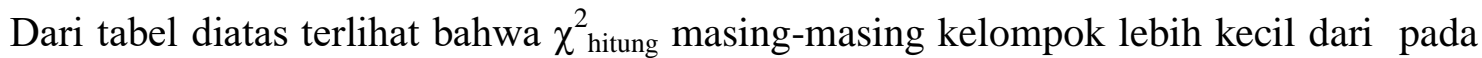
$\chi_{\text {tabel }}^{2}$ dengan taraf signifikan 5\%, sehingga dapat disimpulkan bahwa kedua kelompok berasal dari populasi yang terdistribusi normal.

Untuk menguji homogenitas data dalam penelitian ini digunakan uji F. Pengujian ini dimaksudkan untuk mengetahui homogen atau tidaknya data yang diperoleh dari hasil evaluasi kemampuan berpikir kritis siswa melalui model Problem Based Learning melalui Lesson Study selaku kelas eksperimen serta kelompok yang diajarkan dengan model konvensional selaku kelas kontrol. Berdasarkan hasil pengujian dengan menggunakan uji $\mathrm{F}$ yaitu membagi varian terbesar dengan varian terkecil diperoleh data $F_{\text {hitung }}=1.30$ dan $F_{\text {tabel }}=$ 1,88 pada taraf signifikan $5 \%$ dengan dk penyebut $28-1$ dan dk pembilang $30-1$ dengan $F_{h i t u n g}$ $<\mathrm{F}_{\text {tabel }}=1.30<1,88$. Dengan demikian kemampuan siswa dari kedua kelompok adalah homogen. Hipotesis yang diajukan pada sub bab sebelumnya akan diuji kebenarannya dengan menggunakan uji-t. Adapun kriterianya apabila t-hitung > t-tabel maka $\mathrm{H}_{\mathrm{a}}$ yang di ajukan diterima dan $\mathrm{H}_{\mathrm{o}}$ ditolak. Berdasarkan hasil analisis pada lampiran. Diperoleh harga t-hitung $=1.25$ dan t-tabel $=0,07$ pada taraf signifikan 5\% dengan $\mathrm{df}=56$. Yang berarti bahwa "Ada pengaruh pembelajaran Problem Based Learning melalui Lesson Study terhadap kemampuan berpikir kritis siswa pada materi usaha dan energi kelas X SMA SMA Al-Hamzar Tembeng Putik Tahun pelajaran 2016/2017'. Hasil yang diperoleh sesuai dengan penelitian yang dilakukan oleh Abdul Azizi (2016), dengan judul penelitian "Implementasi Model Problem Based Learning(PBL) Dalam Meningkatkan kemampuan Berpikir Kritis Mahasiswa Melalui Lesson Study" yaitu kemampuan berpikir kritis mahasiswa pada mata kuliah Matematika Ekonomi dapat ditingkatkan dengan menggunakan problem based learning melalui kegiatan lesson study. Hasil serupa dikemukakan oleh Syahroni Ejin (2016) dengan judul penelitian "Pengaruh Model Problem Based Learning (PBL) Terhadap Pemahaman Konsep dan Keterampilan Berpikir Kritis Siswa", diperoleh aktivitas siswa mengalami peningkatan, respon siswa terhadap proses pembelajaran memberikan respon positif, seluruh siswa mencapai ketuntasan penguasaan konsep dan keterampilan berpikir kritis. Penelitian lain dilakukan oleh Riski Fitriani (2015) dengan judul Pengaruh strategi pembelajaran problem based learning dan inkuiri terbimbing terhadap keterampilan metakognitif, berpikir kritis, dan hasil belajar kognitif, hasil penelitiannya menunjukkan ada pengaruh strategi pembelajaran Problem Based Learning (PBL) terhadap hasil belajar kognitif siswa.

\section{KESIMPULAN}

Berdasarkan hasil penelitian dan analisis data serta pembahasan dapat diambil kesimpulan yaitu:"Ada pengaruh model pembelajaran Problem Based Learning melalui Lesson Study terhadap kemampuan berpikir kritis siswa pada materi usaha dan energi kelas X SMA Al-Hamzar Tembeng Putik Tahun pelajaran 2016/2017”.

\section{SARAN}

Diharapkan kepada pendidik untuk bisa mengasah kemampuan berpikir kritis siswa untuk melihat perkembangan siswa dalam memahami dan mengaplikasikan pengetahuan yang sudah dimilikinya. Diharapkan kepada pendidik untuk menggunakan model pembelajaran yang dapat membuat rasa ingin tahu siswa terhadap suatu masalah dan mengaplikasikan pengetahuannya dengan maksimal melalui berbagai macam evaluasi pembelajaran termasuk melalui kegiatan Lesson Study untuk melihat ketercapaian proses pembelajaran yang dilakukan pendidik pada kegiatan belajar mengajar. 


\section{DAFTAR PUSTAKA}

Abdul Aziz1,Shahibul Ahyan2\& Lalu Muhammad Fauzi. (2016). Implementasi Model Problem Based Learning( $\mathrm{Pbl})$ Dalam Meningkatkankemampuan Berpikir Kritis Mahasiswa Melalui Lesson Study. Jurnal ElemenVol. 2 No. 1, Januari 2016, hal. 83 91.

Arikunto, Suharsimi. (2010). Prosedur Penelitian Suatu Pendekatan Praktik. Jakarta: PT Rineka Cipta.

Arikunto, Suharsimi, dkk. (2012). Penelitian Tindakan Kelas. Jakarta: Bumi Aksara.

Baharuddin, and Esa Nur Wahyuni. (2015). Teori Belajar dan Pembelajaran. Yogyakarta: Ar-Ruzz Media.

Ennis, Roberh. (1995). Critical Thinking. Universitas of Illinois.The New York Times Company. United States of Amerika.

Hamruni. (2009). Strategi dan Model-Model Pembelajaran Aktif Menyenangkan. Yogyakarta: Fakultas Tarbiah UIN Sunan Kalijaga.

Hasbullah.(2005). Dasar-Dasar Ilmu Pendidikan Edisi Revisi. Jakarta: PT Raja Grafindo Persada.

Hakim, Lukman. (2012). Perencanaan Pembelajaran. Bandung: CV WACANA PRIMA. Hamalik, Oemar. (2001). Proses Belajar Mengajar. Bandung : Remaja Rosdakarya.

Hanafiah, Nanang dan Cucu Suhana. (2012). Konsep Strategi Pembelajaran. Bandung: Rafika Aditama.

Huda, Miftahul. (2013). Model-Model Pengajaran dan Pembelajaran. Yogyakarta: Pustaka Pelajar.

Konsep dan Implementasi Kurikulum (2013). Paparan Wakil Menteri Pendidikan dan Kebudayaan RI Bidang Pendidikan. Jakarta: Kementrian Pendidikan dan Kebudayaan.

Kowiyah. Kemampuan berfikir kritis. Jurnal pendidikan dasar, (online), 3 (5): 175-177, (http://www.um.ac.id ), diakses 27 februari 2017.

Masaaki, Sato. (2012). Dialog dan Kolaborasi di Sekolah Menengah Pertama Praktek Learning Community. Pelita.

Nur, Muhammad. (2011). Model Pembelajaran Berdasarkan Masalah. Surabaya: Pusat Sains dan Matematika Sekolah UNESA.

Purwanto. (2008). Evaluasi Hasil Belajar. Surakarta: Pustaka Belajar.

Raharja, Bagus dkk. (2014). Panduan Belajar Fisika 2A SMA kelas XI . Jakarta: Yudhistira

Riski Fitriyani, Aloysius Duran Corebima, Ibrohim Ibrohim. (2015). Pengaruh strategi pembelajaran problem based learning dan inkuiri terbimbing terhadap keterampilan metakognitif, berpikir kritis, dan hasil belajar kognitif siswa sma. Jurnal Pendidikan Sains. Vol 3 No 4. 2015. journal.um.ac.id

Riyanto, Yatim. (2010). Metodologi Penelitian Pendidikan. Surabaya: SIC.

Sato, Manabu. (2012). Mereformasi Sekolah Konsep dan Praktik Komunitas Belajar. Pelita. Sugianto. (2010). Model-Model Pembelajaran. Surakarta: Yuma Pustaka.

Sugiyono. (2010). Statistika Untuk Penelitian. Bandung: Alfabeta.

Sugiyono. (2011). Metode Penelitian Pendidikan Pendekatan Kuantitatif, Kualitatif, dan R \& $D$. Bandung: Alfabeta

Sugiyono. (2012). Metode Penelitian Kuantitatif Kualitatif Dan $R \&$ D. Bandung: Alfabeta. Sugiyono. (2012). Statistik Untuk Penelitian. Bandung: Alfabeta.

Sugiyono. (2013). Metode Penelitian Pendidikan Pendekatan Kuantitatif, Kualitatif, dan $R$ \& D. Bandung: Alfabeta. 
Sugiyono. (2014). Metode Penelitian Kuantitatif Kualitatif Dan $R \&$ D. Bandung: Alfabeta.

Suprijono, Agus. (2009). Cooperative Learning. Teori dan Aplikasi Paikem. Yogyakarta: Pustaka Pelajar.

Syamsuri, Istamar dan Ibrahim. (2008). Lesson Study (Studi Pembelajaran). Malang: FMIPA UNM.

Syahroni Ejin. (2016). Pengaruh Model Problem Based Learning (PBL Terhadap Pemahaman Konsep dan Keterampilan Berpikir Kritis Siswa Kelas IV SDN Jambu Hilir Baluti 2 Mata Pelajaran Ilmu Pengetahuan Alam. Jurnal Pedidikan Vol 1 no 12016.

Yuliana. Penerapan Model Pembelajaran Problem Based Learning (PBL) Berbasis Local Material (LM) Melalui Lesson Study (LS) Untuk Meningkatkan Keterampilan Metakognisi, Keterampilan Inkuiri Dan Hasil Belajar Siswa Kelas X5 Sman 1 Mojo Kediri Pada Materi Tumbuhan, FKIP UNS, 22 April 2015. (Online), (https://www.google.co.id), di Akses 23 Februari 2017. 